\title{
Pojęcie i Cel Kary w Kościele RYS HISTORYCZNO-PRAWNY
}

\section{Wstęp}

Kościołowi przysługuje własne, wrodzone i niezależne od jakiejkolwiek władzy ludzkiej prawo karania podległych sobie wiernych ${ }^{1}$. Ci, którym przysługuje to prawo, powinni jednak pamiętać, że na pierwszym miejscu są oni pasterzami swojej owczarni, a nie sędziami wymierzającymi karę.

Ojcowie Soboru Trydenckiego (1545-1563) rozwijając tę myśl, pouczali: „należy upomnieć biskupów, aby pamiętali, że są pasterzami, a nie tyranami, oraz że powinni tak kierować poddanymi, aby raczej miłowali kul.p

* Ks. dr hab., Katolicki Uniwersytet Lubelski Jana Pawła II, e-mail: kmikolajczuk@

1 Por. E. Sztafrowski, Prawo kanoniczne wo okresie odnowy soborowej. Podręcznik dla duchowieństwa, t. 2, Warszawa 1979, s. 562. F. Bączkowicz rozwija tę myśl, wskazując, że „Prawo karania jest Kościołowi wrodzone; wynika bowiem z samej natury społecznej Kościoła. Jako społeczność doskonała musi Kościół mieć prawo nie tylko wydawania przepisów i rozstrzygania sporów, lecz także zmuszania opornych, którzy by do jego przepisów lub wyroków zastosować się nie chcieli. [...] Prawo karania w Kościele nie jest zapożyczone od innej władzy, lecz jest prawem własnym Kościoła, nadanem mu przez samego Założyciela, Chrystusa Pana. Stąd też w wykonywaniu tej władzy jest Kościół niezależny od innej władzy, zwłaszcza państwowej. Pismo św. na wielu miejscach zawiera świadectwo, że władza karania została Kościołowi nadana przez Chrystusa Pana; Kościół zaś od samego początku swego istnienia zawsze ją wykonywał, a przeciwne zapatrywania niejednokrotnie potępił". F. Bączkowicz, Prawo kanoniczne. Podręcznik dla duchowieństwa, t. 2, Kraków 1933, s. 530-531. Podobny zapis odnajdujemy w komentarzu: J. A. Renken, The Penal Law of the Roman Catholic Church. Commentary on Canons 1311-1399 and 1717-1731 and Other Sources of Penal Law, Ottawa 2015, s. 15. 
ich jak dzieci i braci, a nie panowali nad nimi, oraz aby się starali przez zachęty i napomnienia utrzymać ich $\mathrm{z}$ dala od tego, co niegodziwe, i nie musieli ich karać stosownymi karami, w razie popełnienia przez nich przestępstw. Gdyby zaś wiernym zdarzyło się zgrzeszyć z powodu ludzkiej słabości, biskupi powinni zachować nakaz Apostoła, aby ich przekonywać, zaklinać i ganić we wszelkiej dobroci i cierpliwości, gdyż często «silniej działa na upominanych łaskawość niż surowość, bardziej zachęta niż groźba, bardziej miłość niż moc». Jeżeli zaś z powodu powagi przestępstwa należałoby użyć rózgi, wtedy ostrość winna być stosowana z łaskawością, osąd z miłosierdziem, surowość z łagodnościa, aby lud był zachowany w zbawiennej i koniecznej dyscyplinie bez szorstkości, aby ci, którzy będą ukarani, poprawili się, a jeśli nie chcieliby się opamiętać, to niech inni za zbawiennym przykładem kary, trzymają się z dala od wad. Jest obowiązkiem troskliwych i pobożnych zarazem pasterzy, aby na choroby owiec najpierw stosowali łagodne lekarstwa, a później, gdy ciężar choroby tego się domaga, sięgali po ostrzejsze i cięższe środki zaradcze. Gdyby zaś te środki nie pomogły w usunięciu takich chorób, to wtedy przynajmniej uwolnią inne owce od niebezpieczeństwa zarażenia..."2.

Stąd zastosowanie sankcji karnej stanowi ostateczność, gdy nie skutkują inne środki, o czym w niemalże identycznej treści przypomina prawodawca kodeksowy z 1917 roku $^{3}$. Zawsze jednak należy pamiętać, że istnieją: rady, zachęty i dobre przykłady, ponieważ to „Biskupi kierują powierzonymi sobie poszczególnymi Kościołami jako zastępcy i legaci

2 Sobór Trydencki, [w:] Dokumenty Soborów Powszechnych. Tekst łaciński i polski, t. 4, (opr.) A. Baron, H. Pietras, Kraków 2005, s. 459-461.

${ }^{3}$ Can. $2214 \S 1$ „Nativum et proprium Ecclesiae ius est, independens a qualibet humana auctoritate, coercendi delinquentes sibi subditos poenis tum spiritualibus tum etiam temporalibus. $\S 2$ Prae oculis autem habeatur monitum Conc. Trid., sess. XIII, de ref., cap. 1: «Meminerint Episcopi aliique Ordinarii se pastores non percussores esse, atque ita praeesse sibi subditis oportere, ut non in eis dominentur, sed illos tanquam filios et fratres diligant elaborentque ut hortando et monendo ab illicitis deterreant, ne, ubi deliquerint, debitis eos poenis coercere cogantur; quos tamen si quid per humanam fragilitatem peccare contigerit, illa Apostoli est ab eis servanda praeceptio ut illos arguant, obsecrent, increpent in omni bonitate et patientia, cum saepe plus erga corrigendos agat benevolentia quam austeritas, plus exhortatio quam comminatio, plus caritas quam potestas; sin autem ob delicti gravitatem virga opus erit, tunc cum mansuetudine rigor, cum misericordia iudicium, cum lenitate severitas adhibenda est, ut sine asperitate disciplina, populis salutaris ac necessaria, conservetur et qui correcti fuerint, emendentur aut, si resipiscere noluerint, ceteri, salubri in eos animadversionis exemplo, a vitiis deterreantur»". Codex Iuris Canonici Pii X Pontificis Maximi iussu digestus Benedicti Papae XV auctoritate promulgatus, AAS 9 (1917) pars II [dalej cyt.: CIC/17]. 
Chrystusa radami, zachętami i przykładem, ale także mocą swego autorytetu i świętej władzy, z której jednak korzystają tylko dla budowania swojej trzody w prawdzie i świętości [...] Władza ta, którą w imieniu Chrystusa osobiście sprawuja jest własna, zwyczajna i bezpośrednia, choć jej wykonywanie jest kierowane $\mathrm{w}$ ostatecznej instancji przez najwyższą władzę Kościoła, i ze względu na dobro Kościoła lub wiernych może być w pewnej mierze ograniczane. Na mocy tej władzy biskupi mają święte prawo i obowiązek wobec Pana stanowienia praw dla tych, którzy zostali powierzeni ich władzy, sprawowania sądów i kierowania wszystkim, co należy do dziedziny kultu oraz apostolatu. [...] Biskup powołany przez gospodarza, aby kierował Jego domownikami, powinien mieć przed oczyma przykład Dobrego Pasterza, który nie przyszedł, aby mu służono, lecz aby służyć (por. Mt 20, 28; Mk 10, 45) i dać swoje życie za owce (por. J 10, 11). Wzięty z pośród ludzi i podlegający słabości, może współczuć tym, którzy nie wiedzą i błądzą (por. Hbr 5, 1n)..." 4 .

W związku ze zbliżającą się setną rocznicą promulgacji kodeksu Pio-Benedyktyńskiego z 1917 roku, wydaje się celowym przybliżenie tych historyczno - prawnych zagadnień wskazanych w temacie niniejszego artykułu.

\section{Pojęcie kary}

Zasadnym staje się więc, by najpierw wyjaśnić pojęcie kary w ogólności, aby łatwiej zrozumieć dalsze myśli przewodnie niniejszych rozważań. Karą według M. Myrchy (w znaczeniu ogólnym) nazywamy reakcję na zachowanie się człowieka wykraczającego przeciwko obowiązującym nakazom lub zakazom, to jakby socjologiczne i filozoficzne oblicze kary - posługując się tytułem publikacji Z. Papierkowskiego ${ }^{5}$. W tym pojęciu kara posiada niejednolity charakter, w zależności przez kogo i w jakim celu zostanie wymierzona. Mówimy tu o karze pedagogicznej, admini-

${ }^{4}$ Por. Sobór Watykański II, Konstytucja dogmatyczna o Kościele - Lumen gentium, n. 27, [w:] Sobór Watykański II, Konstytucje, dekrety, deklaracje. Tekst polski. Nowe tłumaczenie, Poznań 2002; E. Sztafrowski, Prawo kanoniczne..., s. 562.

${ }^{5}$ Por. M. Myrcha, Prawo karne. Komentarz do Piatej Księgi Kodeksu Prawa Kanonicznego. Kara - część I - przepisy ogólne, Warszawa 1960, s. 5, Z. Papierkowski, Socjologiczne i filozoficzne oblicze kary, Lublin 1947, s. 5. 
stracyjnej (porządkowej), dyscyplinarnej, umownej i kryminalnej. Kara, w ścisłym słowa znaczeniu, to stosowne działanie społeczne, wyrażone jawnie, zewnętrznie i wyraźnie. Dokonuje się to przez całą grupę społeczna, wprost (zbiorowo), przez jej zwierzchnika lub przedstawiciela, czy też przez pokrzywdzonego. Wszelkie takie działania sygnowane są przez społeczeństwo za czyn uznany przez powszechne prawo karne za przestępstwo ${ }^{6}$.

Ojciec Święty Pius XII (1939-1958) przedłożył Kościołowi szereg przemówień o pojęciu kary, w których przypominał zasady etyki katolickiej niepodzielnie związanej z powyższym zagadnieniem. $Z$ punktu widzenia etyki katolickiej tamtego okresu w pojęciu kary dostrzegamy pięć ważnych elementów. To dolegliwość, władza, przyczyna, wymiar i cel7 Kara ze swej natury powinna być dolegliwością materialną lub duchową. Powinna być cierpieniem odczuwalnym zmysłami przez przestępcę lub pozbawiać go jakiegoś wymiernego dobra, na przykład życia, wolności, własności, określonych uprawnień duchowych lub przywilejów w grupie społecznej. Kolejno kara powinna być wymierzona sprawcy jedynie przez prawowitą władzę (np. kościelną), której podlega. Nie może sam sprawca wymierzyć sobie kary za dokonane przestępstwo, bowiem z ustanowienia Bożego prawo wymierzania kar przysługuje wyłącznie społeczności doskonałej - jaką jest Kościół i państwo ${ }^{8}$.

Kara może być zaaplikowana jedynie za przestępstwo dokonane, albowiem kara z natury swej jest odwetem nałożonym na sprawcę przez społeczność ludzką, za zburzenie porządku prawnego. Skoro nie zaistniało przestępstwo, nie zaistniał również tytuł prawny do wymierzenia tej kary. Niewątpliwie kara ze swej istoty jest złem, które zostało wymierzone sprawcy przestępstwa. Nie jest ono złem dla sprawcy w sytuacji zagro-

${ }^{6}$ Por. M. Myrcha, Prawo karne..., s. 5-6.

7 Tamże, s. 9-10.

8 O tej doskonałości Kościoła i państwa wspominał w 1929 r. papież Pius XI w swej encyklice - Divini illius Magistri. Te dwa doskonałe podmioty są zdolne i uprawnione do wychowawczego posłannictwa. „Państwo jest społecznością doskonała, mającą w sobie wszystkie środki do swego celu, którym jest powszechne, doczesne dobro; dlatego pod tym względem, to jest w stosunku do ogólnego dobra [...] społecznością w której przez chrzest rodzi się człowiek do boskiego życia łaski, jest Kościół, społeczność nadprzyrodzona i powszechna, społeczność doskonała, ponieważ ma w sobie wszystkie środki do swojego celu, jakim jest zbawienie wieczne ludzi, i dlatego w swoim porządku najwyższa...". Pius XI, encyklika - Divini illius Magistri, http://w2.vatican.va/content/pius-xi/la/encyclicals/documents/hf_p-xi_enc_31121929_divini-illius-magistri.html [dostęp: 10.02.2016 r.]. 
żenia karąa . M. Myrcha stwierdza, że „na nazwę kary zasługuje wyłącznie kara w stanie wykonania, podczas gdy karze w stanie zagrożenia raczej przysługuje nazwa sankcji karnej ${ }^{10}$. Jak już wspomniano, kara ma stanowić dolegliwość, która jako środek zmierza do osiągnięcia określonego celu społecznego. Tak więc przypadłość ta nie może być celem samym w sobie, lecz jedynie i wyłącznie środkiem do pozyskania innego dobra społecznego ${ }^{11}$.

Prawodawca w Kodeksie Prawa Kanonicznego z 1917 roku podaje określenie kary w kan. 2215. Odnajdujemy tam zapis: Kara kościelna jest pozbawieniem jakiegoś dobra w celu poprawy i ukarania przestępcy, dokonanym przez prawowitą władzę ${ }^{12}$. J. Arias tak to interpretuje: „Pozbawienie dobra: kara może odnosić się tylko do dóbr prawnych, pojmowanych jako prawa osobowe; stąd ukaranie jest pozbawieniem praw osobowych właściwych każdemu wiernemu Kościoła lub nabytych na mocy specjalnej sytuacji prawnej, jaką ma w Kościele. Dokonane przez prawowitą władzę: tak być powinno, ponieważ kara kanoniczna ma charakter publiczny. Władza uprawniona do karania może uczynić to wyłącznie wobec przestępcy, czyli osoby, która pogwałciła normę karną z wystarczającą świadomością i wolnością działania. W celu poprawy i ukarania przestępcy: w tych słowach zawiera się cel kary kanonicznej, która ma

${ }^{9}$ Idąc za św. Tomaszem z Akwinu można powiedzieć, że kara z natury jest czymś złym, jednak ze względu na cel stanowi dobro moralne, bowiem prowadzi do naprawy zburzonego porządku społecznego, naruszonego przez dokonane przestępstwo. Ciekawej analizy powyższego zagadnienia dokonuje: P. Belina-Prażmowska, Dlaczego czynimy zło? Trójpodział przyczyn zła moralnego według św. Tomasza z Akwinu, "Rocznik Tomistyczny” 2014, z. 3, s. 113-127. Polecam również interesującą monografię: K. Paczos, Niewiele mniejszy od aniołów. Zagadnienia podstawowe z filozofii wyższej warstwy duszy ludzkiej. Perspektywa Arystotelesa i św. Tomasza z Akwinu, Gdańsk 2005.

${ }^{10}$ Por. M. Myrcha, Prawo karne..., s. 10-12.

11 Tamże, s. 12.

12 CIC/17, can. 2215: „Poena ecclesiastica est privatio alicuius boni ad delinquentis correctionem et delicti punitionem a legitima auctoritate inflicta". Por. J. Arias, Przestępstwa i kary w ogólności, [w:] P. Majer (red.), Codex Iuris Canonici. Kodeks Prawa Kanonicznego. Komentarz. Powszechne i partykularne ustawodawstwo Kościoła katolickiego. Podstawowe akty polskiego prawa wyznaniowego, Kraków 2011, s. 985, E. Sztafrowski, Prawo kanoniczne..., s. 562. M. Myrcha, rozwijając niejako myśl prawodawcy, pisze: „kara jest dolegliwością którą wymierza prawowita władza kościelna, pozbawiając przestępcę jakiegoś dobra materialnego lub duchowego, celem poprawy przestępcy i ustrzeżenia innych ludzi od podobnych karygodnych czynów, a równocześnie zadośćuczynienia sprawiedliwości (ukarania przestępcy)". M. Myrcha, Prawo karne..., s. 17. 
charakter odwetowy, czyli retorsyjny, a jednocześnie zmierza do nawrócenia i poprawy przestępcy..."13.

Godnym odnotowania jest fakt, że w definicji kary prawodawca wskazuje istotne jej składniki, są nimi: przyczyna, przedmiot, władza oraz $\mathrm{cel}^{14}$. Mówiąc o przyczynie należy stwierdzić, że samo przestępstwo nie powoduje kary, lecz zaburzenie porządku społecznego działaniem bezprawnym obliguje do wymierzenia kary. $\mathrm{W}$ obowiązującym porządku prawnym (tamtego okresu), prawo i powinność wymiaru kar przysługiwała wyłącznie społeczności doskonałej - czyli, jak to już wspominano - Kościołowi i państwu. Dokonane przestępstwo poniekąd zmusza społeczność do wymierzania kary. Kara zaś jest działaniem odwetowym ze strony społeczeństwa przeciwko dezorganizacji społecznej, spowodowanej przestępstwem. Ta generalna zasada znalazła swój wyraz w Kodeksie z 1917 roku. Przyczyną kary kościelnej jest popełnione przestępstwo. Prawodawca wyraża tę myśl w kan. 2215 w słowach: ad deliquentis correctionem et delicti punitionem. Z dyspozycji zawartych w kan. $2214 \S 1$, $2216^{15}, 2228^{16}, 2233^{17}$ jasno też wynika, że podstawą kary kościelnej jest

13 J. Arias, Przestępstwa..., s. 985.

14 Por. M. Myrcha, Prawo karne..., s. 17.

${ }^{15} \mathrm{CIC} / 17$, can. 2216: „In Ecclesia delinquentes plectuntur: $1^{\circ}$ Poenis medicinalibus seu censuris; $2^{\circ}$ Poenis vindicativis; $3^{\circ}$ Remediis poenalibus et poenitentiis". Prawodawca w powyższym kanonie dokonuje podziału kar na: kary poprawcze - cenzury (poenae medicinales), o ile dążą ku poprawie przestępcy; kary odwetowe (poenae vindicativae), gdy te prowadzą do wyrównania naruszonego porządku publicznego; środki zaradcze (remedia poenalia) i pokuty (poenitentiae). Chociaż te pierwsze nie są wprost karami, lecz zmierzają do zapobieżenia przestępstwom, to w wyjątkowych przypadkach mogą zastąpić karę (kan. 2309 § 3), lub też ją zaostrzyć (kan. 2311 § 2). Pokuty natomiast nakładane są w zakresie zewnętrznym przez stosowną władzę kościelną. Mają one na celu zadośćuczynienie Bogu i bliźniemu. W zakresie zaś zewnętrznym ukierunkowane są na zadośćuczynienie społeczności, mogą być przyjęte dobrowolnie lub nałożone przez kompetentną władzę - i jedynie wtedy mają charakter kary. E. Sztafrowski, Prawo kanoniczne..., s. 563, F. Bączkowicz, Prawo kanoniczne. Podręcznik dla duchowieństwa, t. 3, Opole 1958, s. 384.

${ }^{16} \mathrm{CIC} / 17$, can. 2228: „Poena lege statuta non incurritur, nisi delictum fuerit in suo genere perfectum secundum proprietatem verborum legis". E. Sztafrowski, powołując się na F. Bączkowicza, formułuje to tak: „Przestępca nie zaciąga przewidzianej w ustawie kary, jeżeli przestępstwo nie jest w swoim rodzaju dokonane według brzmienia słów ustawy (por. kan. 2228). Idzie tutaj o warunki obiektywne i subiektywne określone przez ustawę dla danego przestępstwa". E. Sztafrowski, Prawo kanoniczne..., s. 569. F. Bączkowicz, Prawo kanoniczne..., t. 3, s. 399.

$17 \mathrm{CIC} / 17$, can. 2233: „§ 1. Nulla poena infligi potest, nisi certo constet delictum commissum fuisse et non esse legitime praescriptum. $§ 2$. Licet id legitime constet, si agatur de infligenda censura, reus reprehendatur ac moneatur ut a contumacia recedat ad normam can. $2242 \S 3$, dato, si prudenti eiusdem iudicis vel Superioris arbitrio casus id ferat, 
przestępstwo dokonane zgodnie z wymogami kan. $2195^{18}$ oraz usiłowanie przestępstwa zgodnie z kan. $2212 \S 4^{19}, 2213^{20}$. Następstwem powyższej zasady jest to, że kara nie może być wymierzona osobom niewinnym lub za przestępstwo tak zwane obce. Zasada ta jest bezwzględną i nie dopuszcza żadnego wyjątku. Według M. Myrchy ,jeśli więc w związku z karą, na jaką skazano sprawcę przestępstwa, osoby niewinne zmuszone są znosić pewne dolegliwości, np. w wypadku wymiaru interdyktu lokalnego lub personalnego ogólnego, to dolegliwości te w stosunku do tychże niewinnych osób nie stanowią kary, lecz są to zarządzenia administracyjne, których zastosowanie jest konieczne, ażeby kara mogła osiągnąć swój cel”21.

Kolejno M. Myrcha, wskazując na przedmiot jako istotny składnik kary, opisuje najpierw odpłatę ze strony społeczeństwa, bowiem, jak twierdzi,

congruo ad resipiscentiam tempore; contumacia persistente, censura infligi potest". Nie wolno zatem wymierzać jakiejkolwiek kary, dopóki nie ustali się, że przestępstwo zostało popełnione i nie uległo przedawnieniu. Należy również pamiętać, że przy wymierzaniu kar poprawczych należy upomnieć i skarcić winnego, aby ten powstrzymał się od uporu. Jeśli pomimo tego trwa w uporze, należy wymierzyć mu karę poprawczą. E. Sztafrowski, Prawo kanoniczne..., s. 572.

${ }_{18} \mathrm{CIC} / 17$, can. 2195: „§ 1. Nomine delicti, iure ecclesiastico, intelligitur externa et moralitet imputabilis legis violatio cui addita sit sanctio canonica saltem indeterminata. $\S 2$. Nisi ex adiunctis aliud appareat, quae dicuntur de delictis, applicantur etami violationibus praecepti cui poenalis sanctio adnexa sit". Przestępstwo oznacza zewnętrzne i moralnie poczytalne naruszenie ustawy, do której dołączono sankcję karną, choćby nieokreśloną. Według E. Sztafrowskiego powyższa definicja wskazuje na trzy elementy składowe: „1 $1^{\text {o }}$ Przestępstwo jest zewnętrznym naruszeniem przepisu. Nie stanowi zatem przestępstwa (choć będzie grzechem) sama myśl, czy nawet chęć naruszenia prawa. Czyn jednak oznacza tu również zaniechanie tego, co powinno być podjęte, wykonane. $2^{\mathrm{O}}$ Działanie przestępcze zakłada poczytalność, a wiec wymagane są wszystkie elementy suponujące winę moralną. $3^{\circ}$ Nie każde jednak przekroczenie przepisu powoduje zaistnienie przestępstwa, lecz jedynie takiego przepisu, do którego prawodawca dołączył sankcję karną". Dalej ten sam Autor pisze: „Na równi z ustawą karną idzie rozkaz (praeceptum), do którego dołączono zagrożenie karą. Tak więc jego naruszenie powoduje zaistnienia przestępstwa". E. Sztafrowski, Prawo kanoniczne..., s. 552-553.

${ }_{19} \mathrm{CIC} / 17$, can. 2212: „§ 4 . Si conatus delicti peculiari poena in lege muletetur, verum constituit delictum".

${ }^{20} \mathrm{CIC} / 17$, can. 2213: „§ 1. Delicti conatus suam habet imputabilitatem, eo maiorem, quo magis ad consummationem accedit, quanquam minorem prae delicto consummato, salvo praescripto $\S 3$. $\S 2$. Delictum frustratum magis culpabile est, quam simplex delicti conatus. § 3. Ab omni imputabilitate liberatur qui sponte ab incepta delicti exsecutione destiterit, si nullum ex conatu damnum aut scandalum ortum sit".

${ }^{21}$ M. Myrcha, Prawo karne..., s. 17-18. Wiele interesujących informacji odnajdujemy również u F. Bączkowicza, który wnikliwie wyjaśnia zagadnienia związane z usiłowaniem przestępstwa: pojęcie, warunki usiłowania, podział, poczytalność. F. Bączkowicz, Prawo kanoniczne..., t. 2, s. 546-547. 
ta stanowi istotny element kary kościelnej. Opiera się ona na najistotniejszych zasadach prawa naturalnego i jest wspólną wszystkim społeczeństwom. Myślą przewodnią kary kościelnej jest odwet - odpłata. Jaką winna być odpłata? - pyta Autor. „Ze względu na to, że przestępstwo, z racji spowodowanego bezprawia (szkody materialnej) oraz winy występującej po stronie sprawcy, stanowi zamach na żywotne interesy społeczne, jest więc czymś złym dla społeczności, stąd i odwet ze strony społeczeństwa musi być czymś złym, wyrażającym się w cierpieniu, czy też pozbawieniu pewnych dóbr sprawcy przestępstwa, przez tę społeczność; ściśle mówiąc, przez władzę chroniącą porządku społecznego. Wskazuje na to kan. 2215, w słowach: Poena est privatio alicuius boni" 22 .

Przed kodeksem Pio-Benedyktyńskim kara kościelna, a także i ta definiowana przez ustawodawstwo świeckie, określana była jako: malum passionis aut privationis. Takie pojęcie kary było uzasadnione, bowiem historia pokazuje, że w Kościele stosowane były liczne kary cielesne ${ }^{23}$. Kodeks Prawa Kanonicznego z 1917 roku wskazuje, że Kościół, podobnie jak i państwo, nie chce wymierzać takich kar, bowiem te nie są zgodne z zasadami polityki kryminalnej. Należy więc jasno stwierdzić, że przedmiotem kary kościelnej jest każda dolegliwość (z wyjątkiem cielesnej), jaka powstaje wskutek pozbawienia sprawcy przestępstwa określonego dobra, rzeczy lub praw, czy też możliwości korzystania z tego dobra lub praw, przysługujących sprawcy przed popełnieniem przestępstwa. Przez dobra, jakich pozbawić może kara kościelna, rozumieć należy te wszystkie i wyłącznie te, którymi Kościół może dysponować w zakresie zewnętrznym²4. Zatem przedmiotem kary kościelnej są wyłącznie te dobra, które z racji nabycia, posiadania, ochrony lub użycia podlegają jego jurysdykcji w zakresie zewnętrznym ${ }^{25}$. Warto wspomnieć, że przedmiotem kary kościelnej są również dobra naturalne, przez Boga dane wszystkim ludziom, i te,

${ }^{22}$ M. Myrcha, Prawo karne..., s. 19.

${ }^{23}$ Po wiele interesujących informacji odsyłam do: L. Lyons, Historia kar cielesnych, Warszawa 2010; W. Ambrozik, Od kaźni i tortur do uwięzionej socjalizacji. O genezie i rozwoju systemu profilaktyki i resocjalizacji, „Studia Edukacyjne” 2013, nr 24, s. 27-36.

${ }^{24}$ E. Wilemska, Kary kościelne, [w:] Encyklopedia Katolicka, t. 8, Lublin 2000, kol. 928.

${ }^{25}$ M. Myrcha podaje następujący katalog: „Takimi są: dobra duchowe lub doczesne, które Kościół własną powagą ustanowił i wobec tego dowolnie nimi może dysponować. Do nich zaliczają się: beneficja i oficja kościelne, odpusty, prawo patronatu, ponadto także dobra, które przysługują sprawcy na podstawie praw przyrodzonych; są nimi dobra nadprzyrodzone, które z ustanowienia Chrystusa Pana przysługują wiernym, lecz znajdują się w administracji, ochronie lub dystrybucji władzy kościelnej, jakimi są sakramenta Św., władza jurysdykcji, uczestnictwo w obrzędach Bożych”. M. Myrcha, Prawo karne..., s. 20. 
które zostały powierzone pieczy Kościoła - wolność, sława, własność. Bez wątpienia nie są przedmiotem kary kościelnej dobra lub prawa przynależne do kompetencji władzy świeckiej. Dobra duchowe, udzielone wiernym przez Stwórcę natury oraz Chrystusa Pana, założyciela Kościoła, nie mieszczą się również w katalogu przedmiotów kary kościelnej. Do nich zaliczyć możemy: charakter sakramentalny, władzę święceń, łaskę uświęcającą czy też uczynkowa, jak również dobra, które bezpośrednio przysługują członkom Kościoła przez wzgląd na ich osobiste zasługi, jak: pobożne uczynki czy też prywatne modlitwy ${ }^{26}$.

Władza - to kolejny, istotny składnik kary. W Kościele stosowanie sankcji karnych należy wyłącznie do władzy publicznej, z wyłączeniem osób prywatnych - kan. 1934²7. W kan. 2215, zawierającym definicję kary, prawodawca nie podaje, jaka władza jest kompetentna do wymiaru kary. Wydaje się, że to zagadnienie jest przedmiotem tytułu 5, księgi V, kan. $2220-2225^{28}$. Z powyższych kan. 2220-2225, jak i ogólnych zasad prawa

${ }^{26}$ Tamże, s. 20-21. Powyższe zestawienie uzupełnia E. Wilemska: „Przedmiotem kary kościelnej jest dolegliwość, jakiej doznaje przestępca wskutek pozbawienia go określonych dóbr lub uprawnień do korzystania z nich; k.k. [tu: kara kościelna - K.M.] może pozbawić dóbr podlegających kompetencji władzy kościelnej, przedmiotem k.k. nie mogą być takie dobra, które chrześcijanie otrzymują bezpośrednio od Boga, jak łaska uświęcająca, i takie dobra, które podlegają wyłącznej kompetencji władzy świeckiej, np. urzędy państwowe; mogą to być: $1^{\circ}$ dobra duchowe, które z ustanowienia Chrystusa przysługują wiernym, ale powierzone są administracji władzy kościelnej, jak: sakramenty, władza nauczania, uświęcania i rządzenia Kościołem, $2^{\circ}$ dobra duchowe, które Kościół własną powagą ustanowił, jak: sakramentalia, urzędy i godności kościelne, $3^{\circ}$ dobra doczesne, które znajdują się w dyspozycji Kościoła jako niezbędne środki do realizacji jego misji nadprzyrodzonej, jak: dobre imię, pensje kościelne, majątek kościelny". E. Wilemska, Kary..., kol. 928.

${ }_{27}$ CIC/17, can. 1934: "Actio, seu accusatio criminalis uni promotori iustitiae, ceteris omnibus exclusis, reservatur".

${ }^{28} \mathrm{CIC} / 17$, can. 2220-2225: „Can. 2220. $§ 1$. Qui pollent potestate leges ferendi vel praecepta imponendi, possunt quoque legi vel praecepto poenas adnectere; qui iudiciali tantum, possunt sollummodo poenas, legitime statutas, ad normam iuris applicare. $\S 2$. Vicarius Generalis sine mandato speciali non habet potestatem infligendi poenas. Can. 2221. Legislativam habentes potestatem, possunt intra limites suae iurisdictionis, non solum legem a se vel a decessoribus latam, sed etiam, ob peculiaria rerum adiuncta, legem tam divinam, quam ecclesiasticam a superiore potestate latam, In territorio vigentem, congrua poena munire aut poenam lege statutam aggravare. Can. 2222. § 1. Licet lex nullam sanctionem appositam habeat, legitimus tamen Superior potest illius transgressionem, etiam sine praevia poenae comminatione, aliqua iusta poena punire, si scandalum forte datum aut specialis transgressionis gravitas id ferat; secus reus puniri nequit, nisi prius monitus fuerit cum comminatione poenae latae vel ferendae sententiae in casu transgressionis, et nihilominus legem violaverit. § 2. Pariter idem legitimus Superior, licet probabile tantum sit delictum fuisse commissum aut delicti certe commissi poenalis actio praescripta sit, 
publicznego wynika, że kompetentną władzą jest wyłącznie władza kościelna, wyposażona w uprawnienia karania w zakresie zewnętrznym. Można to uzasadnić w sposób następujący: kara kościelna ze swej natury jest właściwą sobie reakcją ze strony społeczności kościelnej (władzy kościelnej), do której należy obowiązek zachowania porządku prawno-społecznego, który pogwałcił przestępca swym bezprawnym postępowaniem w sposób zawiniony, z wystarczającą świadomością i wolnością działania ${ }^{29}$. Jak twierdzi M. Myrcha: „z racji braku wymiaru przez prawowitą władzę pokuty - dobrowolnie przyjęte - nie mają charakteru kary, będą natomiast kara, gdy zostaną nałożone przez właściwą władzę kościelną" ${ }^{30}$.

non solum ius, sed etiam officium habet non promovendi clericum de cuius idoneitate non constat, et, ad scandalum evitandum, prohibendi clerico exercitium sacri ministerii aut etiam eundem ab officio, ad normam iuris, amovendi; quae in casu non habent rationem poenae. Can. 2223. § 1 . In poenis applicandis iudex nequit poenam determinatam augere, nisi extraordinaria adiuncta aggravantia id exigant. § 2 . Si lex in statuenda poena ferendae sententiae facultativis verbis utatur, commitittitur prudentiae et conscientiae iudicis eam infligere, vel, si poena fuerit determinata, temperare. $\S 3$. Si vero lex utatur verbis praeceptivis, ordinarie poena infligenda est; sed conscientiae et prudentiae iudicis vel Superioris committitur: $1^{\circ}$ Poenae applicationem ad tempus magis opportunum differre, si ex praepropera rei punitione maiora mala eventura praevideantur; $2^{\circ} \mathrm{A}$ poena infligenda abstinere, si reus perfecte fuerit emendatus, et scandalum reparaverit, aut sufficienter punitus sit vel puniendus praevideatur poenis auctoritate civili sanctis; $3^{\circ}$ Poenam determinatam temperare vel loco ipsius aliquod remedium poenale adhibere aut aliquam poenitentiam iniungere, si detur circumstantia imputabilitatem notabiliter minuens, vel habeatur quidem rei emendatio aut inflicta a civili auctoritate castigatio, sed iudex vel Superior opportunam praeterea ducat mitiorem aliquam punitionem. $\S 4$. Poenam latae sententiae declarare generatim committitur prudentiae Superioris; sed sive ad instantiam partis cuius interest, sive bono communi ita exigente, sententia declaratoria dari debet.Can. 2224. $\S 1$. Ordinarie tot poenae quot delicta. $\S 2$. Si tamen propter numerum delictorum nimius esset poenarum infligendarum cumulus, prudenti iudicis arbitrio relinquitur aut poenam omnium graviorem infligere, addita, si res ferat, aliqua poenitentia vel remedio poenali, aut poenas intra aequos terminos moderari, habita ratione numeri et gravitatis delictorum. $\S$ 3. Si poena constituta sit tum in conatum delicti tum in delictum consummatum, hoc admisso, infligi tantum debet poena in consummatum delictum statuta. Can. 2225. Si poena declaretur vel infligatur per sententiam iudicialem, serventur canonum praescripta circa sententiae iudicialis pronuntiationem; si vero poena latae vel ferendae sententiae inflicta sit ad modum praecepti particularis, scripto aut coram duobus testibus ordinarie declaretur vel irrogetur, indicatis poenae causis, salvo praescripto can. 2193".

${ }^{29}$ Por. J. Arias, Przestepstwa..., s. 985.

${ }_{30}$ M. Myrcha, Prawo karne..., s. 21-22. Warto odnotować za M. Myrcha, że pojęcie kary w polskim Kodeksie karnym z 1932 roku jest niemalże tożsame z tym w Kodeksie prawa kanonicznego z 1917 roku. Tamże, Prawo karne..., s. 22. Po rozważania dotyczące równie interesujących zagadnień zawartych w polskim Kodeksie karnym z początków XX wieku odsyłam do: A. Grześkowiak, K. Wiak, M. Gałązka, R. Hałas, S. Hypś, D. Szeleszczuk (red.), Kodeks karny z 1932 roku, Lublin 2015. 


\section{Cel kary}

W dziejach prawa kanonicznego wymieniane były różne cele kary kościelnej. „Dekret Gracjana, opierając się na nauce Augustyna podkreślał, że kara ma uzasadnienie o tyle, o ile przyczynia się do poprawy przestępcy i innych ludzi; w KPK z 1917 (kan. 2215) prawodawca wskazał, że kara kościelna ma służyć zarówno celowi poprawczemu, jak i odwetowemu; prawodawca hołdował teorii mieszanej, zaś komentatorzy prawa kodeksowego (G. Michel, M. Myrcha) podkreślali cel odwetowy..." ${ }^{\prime 31}$. Pojęcie kary wydaje się, że byłoby niepełne, jeśli poprzestalibyśmy na ustaleniu, czym ona jest, pomijając zagadnienie jej celowości. Zapewne mieści się to w filozofii kary i tam odnaleźć można odpowiedź na pytanie, dlaczego istnieje kara i jakie jest jej uzasadnienie. Należy podkreślić, że cel kary usprawiedliwia jej stosowanie i niewątpliwie uprawnia Kościół, lub państwo, do jej wymiaru. „Cele, które mogą przyświecać karze, są różnorodne: odpłata, zapobieżenie ogólne, zapobieżenie szczególne"32.

Cel kary pokrywa się cząstkowo z jej istotą i wynika z niej samej. Tak więc istotnym celem kary jest odwet. „Można podnieść zarzut, że istota kary nie może być jej celem. Co innego jest istota pewnej instytucji, a co innego jej cel. Istota tkwi w danym urządzeniu, stanowi niejako jego rdzeń, cel natomiast znajduje się poza nim, jako możliwość, do której dane urządzenie zdąża. Istota nie jest nigdy w stanie uzasadnić danego urządzenia, może go jedynie wytłumaczyć, podać jego zrozumienie. Uzasadnienia należy szukać poza danym urządzeniem i jego istota, $\mathrm{w}$ tym co nazywamy celem. Zarzut jest jednak niesłuszny. «Istota może być ściśle związana z celem. W pewnych wypadkach cel może być wynikiem właściwości pewnej rzeczy, może wypływać z jej istoty. Istotą drzewa nie jest jego przeznaczenie, tylko czynniki składowe. Inaczej natomiast będzie z bronią. Istotą broni, bez względu na jej materiał czy budowę jest to, że służy do napaści lub obrony. Cel więc decyduje o istocie. Podobnie rzecz ma się z karą. Cel kary wynika z jej istoty, albowiem kara, z przeznaczenia swego, nie służy dla przyjemności, lecz dla zadawania dolegliwości. Z tej

${ }^{31}$ E. Wilemska, Kary..., kol. 928; W. Wójcik, J. Krukowski, F. Lempa, (red.), Komentarz do Kodeksu Prawa Kanonicznego z 1983 r. Księga V-Dobra doczesne Kościoła, Księga VI - Sankcje $w$ Kościele, t. 4, Lublin 1987, s. 160.

${ }^{32}$ M. Myrcha, Prawo karne..., s. 24. 
racji, nie jest rzeczą nielogiczną upatrywać w istocie kary (odpłacie) zarazem i cel kary (odpłatę)»"33.

Innym i kolejnym celem kary jest cel pedagogiczny - kara ma służyć do oddziaływania na innych członków społeczeństwa, ma powstrzymywać ich od popełniania ewentualnego przestępstwa. M. Myrcha zdecydowanie twierdzi, idąc za myślą S. Śliwińskiego, że „można śmiało zaryzykować twierdzenie, że w każdym człowieku tkwią, w większej lub mniejszej mierze, pierwiastki kryminalne. Wynika to ze skażonej grzechem natury ludzkiej, dążącej do nieograniczonej swobody, która musi być regulowana, aby umożliwić współżycie między ludźmi. Pokusa wkroczenia $\mathrm{w}$ dziedziną obca, celem rozszerzenia własnej swobody, prowadzi często do zatargu z prawem, nie wyłączając prawa karnego" ${ }^{\prime 4}$. S. Śliwiński, kontynuując powyższą myśl, podkreśla: „aby więc powstrzymać te drzemiące w każdym człowieku skłonności do naruszenia prawa, społeczeństwo uznało jako nieodzowną konieczność wprowadzenia kary, mianowicie w postaci jej zagrożenia, wymiaru w razie popełnienia przestępstwa i jej wykonania. Kara ma odstraszać ludzi od popełniania przestępstw, odstraszać przez to, że grozi, że jest wymierzana i że jest wykonywana"35.

Niezasadny jest więc zarzut przeciw prewencji generalnej stwierdzający, że jest ona bezużyteczna, kiedy przestępstwa są stale popełniane. Nie wiemy, jak funkcjonowałoby na co dzień społeczeństwo, kiedy zabrakłoby kary za naruszenie prawa. „Prewencja generalna nie wymaga, jak by się to zdawało, kar odznaczających się nadzwyczajną srogością. Dla przeciętnego ogółu wystarczają w zupełności zagrożenia karne odpowiadające humanitarnym zasadom. Sadystyczne zagrożenia karne mijają się z celem dlatego, że dla przeciętnego ogółu są niepotrzebne i wywołują jedynie niechęć i poczucie niesprawiedliwości, dla pewnych zaś jednostek, których żadna sankcja nie potrafi odstraszyć, są również pozbawione znaczenia. Nie można jednak zaprzeczyć, że w pewnych okolicznościach wzmożonej przestępczości ustawodawca sięgać musi do nadzwyczajnie surowych środków karnych"36.

Kolejnym celem kary jest prewencja szczególna, która w przeciwieństwie do prewencji generalnej koncentruje się wokół sprawcy przestępstwa. Kara, przez swe oddziaływanie tak fizyczne, jak i psychiczne, ma

${ }^{33}$ S. Śliwiński, Prawo karne, Warszawa 1946, s. 436, M. Myrcha, Prawo karne..., s. 24-25.

${ }^{34}$ S. Śliwiński, Prawo..., s. 436. M. Myrcha, Prawo karne..., s. 25.

35 S. Śliwiński, Prawo..., s. 437.

${ }^{36}$ M. Myrcha, Prawo karne..., s. 25-26. 
zapobiec przestępstwu, ma poprawić przestępcę, moralnie go podźwignać i odstraszyć od popełnienia dalszych czynów karalnych. W pewnych ciężkich przypadkach prewencja szczególna nie waha się przed użyciem „eliminacji zupełnej” przestępcy ze społeczeństwa, w postaci dożywotniego pozbawienia wolności lub kary śmierci ${ }^{37}$.

Zasadnym wydaje się postawić pytanie, który cel da się łatwiej osiągnać, który jest lepszy i doskonalszy? Z perspektywy społeczeństwa są one niezbędne, konieczne i potrzebne. Cel odstraszenia przestępcy za pomocą kar najbardziej okrutnych, takich jak: wbicie na pal, łamanie kołem, ćwiartowanie, zakopanie żywcem, palenie na stosie itp., odszedł już w zapomnienie. Nawet kara śmierci, tak powszechna w ubiegłych stuleciach, przestaje być stosowana, przez usunięcie z ustawy bądź na mocy ułaskawienia sprawcy. Pozostaje zatem poprawa sprawcy, która znajduje swe uzasadnione miejsce w kościelnej kodyfikacji z 1917 roku. W kan. 2215 stawia się ją na fundamentalnym miejscu. Pod koniec XIX i na początku XX wieku poprawie przestępcy poświęcono wiele uwagi w ustawodawstwach wielu krajów. Poprawa przestępcy była hasłem niemal powszechnym w połowie XIX wieku. „Okazało się mianowicie, że mimo największych starań sprawca opuszczający mury więzienne [...], rzadko rokuje nadzieję poprawy, a nawet wtedy, gdy ją rokuje, zawodzi i do więzienia powraca" ${ }^{\prime 38}$. Są bowiem przestępcy (na co wskazuje S. Śliwiński), u których

${ }^{37}$ Por. S. Śliwiński, Prawo..., s. 437; T. Chauvin, T. Stawecki, P. Winczorek, Wstęp do prawoznawstwa, Warszawa 2014, s. 115.

${ }^{38}$ J. Makarewicz, Prawo karne. Wykład porównawczy z uwzględnieniem prawa obowiazującego w RP, Lwów-Warszawa 1924, s. 20; M. Myrcha, Prawo karne..., s. 26-27. Warto przywołać chociaż krótką notę biograficzną o prof. J. Makarewiczu. „Makarewicz Juliusz, ur. 5 V 1872 w Samborze, zm. 20 IV 1955 we Lwowie, prawnik, działacz polityczny. W 1889-93 studiował prawo na UJ, 1894 uzyskał doktorat i został sędzią w Sądzie Okręgowym w Krakowie; 1894-95 odbył studia podyplomowe w Halle i Berlinie (uczestniczył m.in. w seminarium Franza von Liszta); od 1897 pracował na UJ na stanowisku docenta w Katedrze Prawa Karnego, od 1904 - prof. nadzwyczajnego, od 1907 - prof. zwyczajnego; 1907 podjął pracę na Uniw. Jana Kazimierza we Lwowie, gdzie sprawował urzędy: kierownika Katedry Prawa Karnego i Procesu Karnego, 1909-10 i 1919-20 - dziekana Wydz. Prawa, 1923-24 - rektora, a 1924-25 - prorektora; od 1920 pełnił funkcję przew. Sekcji Prawa Karnego i gł. redaktora Kodeksu karnego z 1932, zw. „kodeksem M.”; 1925, 1928 i 1930 był senatorem RP; w czasie okupacji niem. brał udział w tajnym nauczaniu; 1945 (z 10 pol. profesorami Uniw. Jana Kazimierza) został aresztowany przez NKWD i wywieziony do obozu w Krasnodonie; po wojnie wykładał na uniwersytecie we Lwowie; był członkiem korespondentem Pol. Akademii Umiejętności (od 1923) i członkiem Amer. Akademii Nauk w Bostonie (od 1933); 1936 został odznaczony orderem Polonia Restituta, a 1937 otrzymał doktorat h.c. Uniwersytetu Jana Kazimierza we Lwowie. M. w poglądach polit. i społ. opierał się na nauce społ. Kościoła, w szczególności pap. Leona XIII; krytykował liberalizm gosp. i wszelkie 
kara zupełnie nie powoduje pozytywnych zmian, a ich resocjalizacja wydaje się być bezcelowa ${ }^{39}$. Skłania to do konkluzji, że prewencja szczególna jedynie incydentalnie $\mathrm{w}$ ramach samej kary potrafi spełnić zakładane zadania. Poprawa przestępcy, jako cel racjonalny, staje się bezużyteczna.

Uruchomiono zatem inne środki, inne cele - uczynienia sprawcy nieszkodliwym. Powyższy zamysł znany był już zorganizowanym społecznościom, znało ją też prawo kanoniczne. Zmiana celu kary nie zmieniła istoty kary jaką jest odwet. „Kara w miarę kultury społecznej zmienia swą postać zewnętrzna, lecz dwie myśli przewodnie: odpłata i celowość nie znikają nigdy, występują tylko w rozmaitych kombinacjach. Skutkiem nadania karze charakteru celowego nie zmienia się wcale istoty: pozostanie ona zawsze odpłata, lecz odpłatą uregulowana, kierowaną pewną refleksją tak jak kara pedagogiczna nie przestaje być karą mimo, że wymierza ją wychowawca z myślą przewodnią pożytku dla samego karanego"40. $\mathrm{Z}$ tego tytułu, tam gdzie kara nie potrafi uzyskać tego, co pragnęlibyśmy osiągnąć przez prewencję specjalną, zastosowano odmienne środki, pozbawione elementu odpłaty.

Są nimi środki zabezpieczające, przez których wprowadzenie starano się osiągnąć unieszkodliwienie sprawcy ${ }^{41}$. Zastosowanie środków zabezpieczających obok kar jest wynikiem oddzielenia odpłaty od zabezpieczenia społecznego. Spowodowało to niewątpliwie pewną dwutorowość w kodeksach karnych wielu społeczności. Wskutek oddzielenia od kary czynnika zabezpieczenia społecznego w postaci środków zabezpieczających kara pozostała tym, czym jest ze swej natury - odpłatą. Rozstrzygającym celem kary ,jest zachowanie w społeczeństwie porządku prawnego, ładu i bezpieczeństwa. Do tego zmierza cały ustrój prawny, do tego zmierza prawo karne, ten cel chce osiągnąć przez stosowanie kary. Na ten cel wyraźnie wskazuje św. Tomasz zaznaczając, że jest ona reakcją porządku prawnego przeciwko bezprawiu spowodowanemu przestępstwem. Jest

postacie totalitaryzmu (komunizm i nar. socjalizm)...". K. Ostaszewski, Makarewicz Juliusz, [w:] Encyklopedia Katolicka, t. 11, Lublin 2006, kol. 865-866.

39 Por. S. Śliwiński, Prawo..., s. 438.

40 J. Makarewicz, Prawo..., s. 20.

${ }^{41}$ Po więcej informacji odsyłam do artykułu: F. Ciepły, Środki zabezpieczajace według koncepcji J. Makarewicza, [w:] A. Grześkowiak (red.), Prawo karne w pogladach Profesora Juliusza Makarewicza, Lublin 2005, s. 289-304; L. K. Paprzycki, System środków zabezpieczajacych w ujęciu Kodeksu karnego z 1932 r. - koncepcja i rzeczywistość, [w:] A. Grześkowiak, K. Wiak, M. Gałązka, R. Hałas, S. Hypś, D. Szeleszczuk (red.), Kodeks..., s. 189-206. 
on istotnym i do jego osiągnięcia winna zmierzać każda władza wymierzająca karę"42.

Warto zaakcentować fakt, że celowość w stosowaniu kar przyczyniła się $\mathrm{w}$ wielu ustawodawstwach do powstania nowych instytucji prawnych, takich jak: warunkowe zawieszenie wykonania kary (warunkowe zasądzenie) i sędziowskie darowanie kary oraz podział przepisów karnych na 3 grupy, dotyczące pełnoletnich, małoletnich oraz osób niepoczytalnych ${ }^{43}$. Komentując powyższe zagadnienia, M. Myrcha wskazuje, że „warunkowe zasądzenie jest rezygnacją z kary, nie tyle bezcelowej z punktu widzenia poprawy, ile wręcz szkodliwej. Umysł ludzki wszedłszy na tory celowości, pyta: po co kara, jeśli nie osiaggnie ona racjonalnego celu? Po co wykonywać karę, np. pozbawienia wolności, jeśli ona nie poprawi, ale wręcz przeciwnie, często jeszcze pogarsza sprawcę? Czy nie lepiej powstrzymać się w tym wypadku z wymiarem lub przynajmniej z wykonaniem kary, jeżeli jest nadzieja, że sprawca i bez odcierpienia kary, a więc i bez odwetu za popełnione przestępstwo, poprawi się? Odpowiedzi na te pytania udziela nam instytucja warunkowego zasądzenia, właściwie warunkowego zawieszenia wykonania grożącej kary, która rezygnuje z odpłaty, a więc z istotnego celu kary, jeśli jest nadzieja, że sprawca się poprawi. Instytucja sędziowskiego darowania kary jest dalszym ciągiem rozważań celowości kary; jest konsekwencją załamania się zasady, że po dokonaniu przestępstwa musi nastąpić kara, jako konieczny akt sprawiedliwości, jest dalszym pomysłem odstąpienia od kary"44.

W podobnym tonie wypowiada się J. Makarewicz, twierdząc, że „jeżeli stosuje się instytucję warunkowego zawieszenia kary na pewien kilkuletni okres próby z tą myślą, że może sprawca swym nienagannym postępowaniem wykaże, iż poprawienie go za pomocą kary jest zbędne, bo on sam się poprawi bez stosowania kary, to co zrobić w takim wypadku, jeżeli już w chwili wydawania wyroku jest pewnym, że sprawca poprawy nie potrzebuje, gdyż już się poprawił albo jego czyn był tylko wynikiem nieszczęśliwego zbiegu okoliczności, chwilowego uniesienia, a sprawca jest osobnikiem o wielkiej wartości moralnej? Logicznie nasuwa się pytanie: po co karać, po co nawet zawieszać warunkowo wykonanie wyroku skazującego, czy nie jest prostszym - kary się zrzec?" ${ }^{45}$. Z powyższych

\footnotetext{
${ }^{42}$ M. Myrcha, Prawo karne..., s. 28.

43 Tamże, s. 28.

${ }^{44}$ Tamże, s. 28-29.

${ }^{45}$ J. Makarewicz, Prawo..., s. 22-23.
} 
rozważań wyłania się instytucja sędziowskiego darowania kary, chociaż jeszcze w bardzo wąskim zakresie, lecz z kolejnymi atutami do dalszej ewolucji.

Obie instytucje odnajdujemy w Kodeksie z 1917 roku oraz w polskim Kodeksie karnym z 1932 roku $^{46}$. Kodeks Pio-Benedyktyński w kan. 2288 wprowadza fakultatywne zawieszenie wykonania kary odwetowej. Prawodawca twierdzi, że o ile przestępca, prowadzący dotąd życie nienaganne, po raz pierwszy dopuścił się przestępstwa, a nie dotyczy to wykonania kary degradacji, depozycji, pozbawienia urzędu lub beneficjum, jak też nie nagli konieczność naprawienia zgorszenia, sędzia może według własnego uznania zawiesić wykonanie kary orzeczonej wyrokiem skazującym, jedynie pod warunkiem, że gdyby skazany w ciągu kolejnych trzech lat popełnił przestępstwo tego samego lub innego rodzaju, będzie podlegał karze przewidzianej za oba przestępstwa ${ }^{47}$. Kolejno w kan. 2223 $\S 2$ i $332^{\circ}$ prawodawca przedkłada sędziowskie prawo łaski (prawo darowania kary $)^{48}$. Odnajdujemy tam zapis, że o ile ustawa przypisuje karę i używa słów fakultatywnych, to sędzia według swego uznania może karę nieoznaczoną nałożyć lub nie, karę zaś oznaczoną może złagodzić. Ten sam sędzia może również wstrzymać się od nałożenia kary, jeżeli winny całkowicie się poprawił i naprawił zgorszenie, bądź też został lub będzie wystarczająco ukarany przez władzę świecką ${ }^{49}$. Przywoływany już z tamtego okresu polski Kodeks karny z 1932 roku omawia warunkowe

${ }^{46}$ Rozporządzenie Prezydenta Rzeczypospolitej z dnia 11 lipca 1932 r. - Kodeks karny (Dz.U. z 1932 r. Nr 60, poz. 571).

47 Por. F. Bączkowicz, Prawo kanoniczne..., t. 2, s. 590. CIC/17, can. 2288: „Exceptis poenis degradationis, depositionis, privationis officii aut beneficii, et nisi urgeat necessitas reparandi scandalum, prudentiae iudicis remittitur, Si reus talis sit ut prima vice post vitam laudabiliter peractam deliquerit, poenae ordinariae per sententiam condemnatoriam inflictae exsecutionem suspendere, ea tamen conditione ut, si reus intra proximum triennium aliud delictum eiusdem vel alterius Genesis commiserit, poenam utrique delicto debitam luat".

${ }^{48} \mathrm{CIC} / 17$, can. 2223: § 2. „Si lex in statuenda poena ferendae sententiae facultativis verbis utatur, commitittitur prudentiae et conscientiae iudicis eam infligere, vel, si poena fuerit determinata, temperare. $\S 3$. Si vero lex utatur verbis praeceptivis, ordinarie poena infligenda est; sed conscientiae et prudentiae iudicis vel Superioris committitur: $2^{\circ}$ A poena infligenda abstinere, si reus perfecte fuerit emendatus, et scandalum reparaverit, aut sufficienter punitus sit vel puniendus praevideatur poenis auctoritate civili sanctis...".

${ }^{49}$ Por. F. Bączkowicz, Prawo kanoniczne..., t. 2, s. 552. E. Sztafrowski, Prawo kanoniczne..., s. 567-568. 
zawieszenie kary w rozdziale IX, w art. 61-64 ${ }^{50}$. Instytucja ta jest prawem sądu, pozostawionym jego uznaniu (sędziowskie prawo łaski: rozdział X, art. $65-68)^{51}$.

Analizując powyższe zagadnienia J. Makarewicz przekonuje, że „myśl o celowości kary doprowadziła do przegrupowania przepisów kodeksu karnego i przeprowadzenia rozróżnienia między trzema typami przepi-

50 „Rozdział IX. Warunkowe zawieszenie wykonania kary. Art. 61. § 1. Sąd może orzec, że wykonanie kary pozbawienia wolności, zasadniczej lub zastępczej, nie przenoszącej 2 lat, zawiesza się na czas od 2 do 5 lat. § 2 . Warunkowe zawieszenie wykonania kary stosuje się do osoby, co do której - ze względu na jej charakter, okoliczności towarzyszące popełnieniu przestępstwa, zachowanie się po jego popełnieniu - przypuszczać należy, że pomimo niewykonania kary nie popełni nowego przestępstwa. §3. Warunkowego zawieszenia wykonania kary nie stosuje się do osób, wymienionych w art. 60. Art. 62. § 1. W przypadku warunkowego zawieszenia wykonania kary, sąd może oddać skazanego pod dozór ochronny na czas zawieszenia; wykonanie dozoru sąd powierza osobom lub instytucjom, zasługującym na zaufanie. § 2. Jeżeli stosunki gospodarcze skazanego na to pozwalają sąd może zobowiązać skazanego, by wynagrodził szkody, zrządzone przestępstwem, w czasie i w rozmiarach ustalonych w wyroku. Art. 63. § 1. Jeżeli w okresie zawieszenia kary skazany popełni nowe przestępstwo z tych samych pobudek lub tego samego rodzaju, co poprzednie, sąd zarządzi wykonanie zawieszonej kary. § 2 . Sąd może zarządzić wykonanie zawieszonej kary, jeżeli w okresie zawieszenia kary skazany popełni inne przestępstwo, niż określone w $\S 1$, uchyla się z pod dozoru, źle się prowadzi lub nie wykona obowiązku wynagrodzenia szkody. Art. 64. Jeżeli w ciągu 3 miesięcy po upływie okresu zawieszenia, sąd nie zarządzi wykonania kary, skazanie uważa się za niebyłe, a skazany odzyskuje prawa wyborcze, prawa udziału w wymiarze sprawiedliwości, prawa rodzicielskie lub opiekuńcze, prawa wykonywania zawodu oraz zdolność do uzyskania innych praw utraconych".

51 „Rozdział X. Warunkowe zwolnienie. Art. 65. § 1. Skazanego na karę pozbawienia wolności można warunkowo zwolnić z odbycia części kary, jeżeli jego zachowanie się w czasie odbywania kary i osobiste warunki pozwalają przypuszczać, że nie popełni nowego przestępstwa. § 2. Skazany powinien odbyć nie mniej, niż dwie trzecie orzeczonej wyrokiem kary, w każdym razie niemniej niż 8 miesięcy, skazany na więzienie dożywotnie - nie mniej niż 15 lat. § 3. Do kary orzeczonej i do kary odbytej nie wlicza się okresu tymczasowego aresztowania, ani darowanej części kary. §4. Skazany, do którego mają być po odbyciu kary zastosowane środki zabezpieczające, nie może być warunkowo zwolniony. Art. 66. §1. W przypadku warunkowego zwolnienia można oddać skazanego pod dozór ochronny na okres próby; wykonanie dozoru powierza się osobom lub instytucjom, zasługującym na zaufanie. $\S 2$. Okres próby obejmuje czas pozostały do odbycia kary, w każdym razie nie mniej niż rok. W razie skazania na więzienie dożywotnie okres próby wynosi 5 lat. Art. 67 . §1. Jeżeli w okresie próby skazany popełni nowe przestępstwo z tych samych pobudek lub tego samego rodzaju, co poprzednie, warunkowe zwolnienie będzie odwołane. $\S 2$. Zwolnienie warunkowe może być odwołane, jeżeli skazany popełni $\mathrm{w}$ okresie próby inne przestępstwo, niż wymienione $\mathrm{w} \S 1$, albo uchyla się z pod dozoru lub źle się prowadzi. $\S 3$. W razie odwołania warunkowego zwolnienia, na poczet kary nie zalicza się okresu, spędzonego na wolności. Art. 68. Jeżeli odwołanie nie nastąpiło w przeciągu 3 miesięcy po upływie okresu próby, karę uważa się za odbytą". 
sów karnych: $1^{\circ}$ między prawem karnym powszechnym, stosowanym do dorosłych i opartym na zasadzie odpłaty, lecz z możnością odstąpienia od niej warunkowo lub bezwarunkowo; $2^{\circ}$ prawem dla nieletnich opartym na zasadzie wykluczenia odpłaty, a zastąpienia jej środkami wychowawczo-poprawczymi, z możliwością stosowania kary w wyjątkowych wypadkach; $3^{\circ}$ prawem o charakterze zabezpieczającym - po odcierpieniu kary lub nawet bez tego, następuje zamknięcie powszechnie groźnej jednostki: recydywiści, niepoczytalni, częściowo anormalni itp., w celu zabezpieczenia społeczeństwa" 52 .

Myśli te odnajdujemy w Kodeksie Prawa Kanonicznego z 1917 roku. Prawodawca wskazuje na dwie grupy przepisów prawnych: dla osób dorosłych - oparte na zasadzie odpłaty, z możliwością odstąpienia od niej (kan. 2223) i dla nieletnich, w stosunku do których warto stosować środki wychowawcze, a nie cenzury i kary odwetowe (kan. 2230) ${ }^{53}$. Kodeks przewiduje również i środki zabezpieczające w postaci karnych środków zaradczych oraz pokut (kan. 2306-2313) ${ }^{54}$. Karnymi środkami zaradczymi

52 J. Makarewicz, Prawo..., s. 23.

${ }_{53} \mathrm{CIC} / 17$, can. 2230: „Impuberes excusantur a poenis latae sententiae, et potius punitionibus educativis, quam censuris aliisve poenis gravioribus vindicativis corrigantur; puberes vero qui eos ad legem violandam induxerint vel cum eis in delictum concurrerint ad normam can. 2209, §§ 1-3, ipsi quidem poenam lege statutam incurrunt". F. Bączkowicz tak to opisuje: „Niedojrzali (impuberes: chłopcy i dziewczęta do 14 lat) nie podlegają karom latae sententiae; należy względem nich stosować raczej środki wychowawczo-poprawcze, niż cenzury lub inne ciężkie kary odwetowe. Dojrzali po 14 roku życia (puberes), którzy niedojrzałych do przekroczenia ustawy nakłonili, lub $\mathrm{w}$ ich przestępstwie brali udział jako wspólnicy fizyczni czy pomocnicy konieczni, podlegają przepisanej ustawą karze". F. Bączkowicz, Prawo kanoniczne..., t. 2, s. 557; E. Sztafrowski, Prawo kanoniczne..., s. 571. Powyższy zapis poucza, że "chociaż ustawa mówi tylko o jednym przestępcy, to jednak w razie uczestniczenia w przestępstwie wspólników koniecznych, o których mowa w kan. 2209 §§ 1-3, wszyscy podlegają tej samej karze, chyba, że ustawa co innego wyraźnie oznacza". E. Sztafrowski, Prawo kanoniczne..., s. 571.

${ }^{54} \mathrm{CIC} / 17$, can. 2306-2313: „Can. 2306. Remedia poenalia sunt: $1^{\circ}$ Monitio; $2^{\circ}$ Correptio; $3^{\circ}$ Praeceptum; $4^{\circ}$ Vigilantia. Can. 2307. Eum qui versatur in proxima occasione delictum committendi vel In quem, ex inquisitione peracta, gravis suspicio cadit delicti commissi, Ordinarius per se vel per interpositam personam moneat. Can. 2308. Si ex alicuius conversatione scandalum vel gravis ordinis perturbatio oriantur, est locus correptioni, ab Ordinario per se vel per interpositam personam, etami per epistolam faciendae, peculiaribus accommodatae conditionibus personae et facti de quo agitur. Can. 2309. §1. Tam monitio quam correptio potest esse vel publica vel secreta. $\S 2$. Correptio vel monitio publica fiat vel coram notario aut duobus testibus, vel per epistolam ita tamen ut de receptione et tenore epistolae ex aliquo documento constet. $\S 3$. Correptio publica fieri tantum potest adversus reum de delicto convictum vel confessum; et est iudicialis, si fiat a iudice pro tribunali sedente vel ab Ordinario ante processum criminalem. § 4. Correptio iudicialis vel 
są: $1^{\circ}$ upomnienie (monitio), $2^{\circ}$ nagana (correptio), $3^{\circ}$ nakaz (praeceptum) i $4^{\circ}$ nadzór (vigilantia). Na określenie ich prawodawca używa podwójnej nazwy: środki karne i zaradcze. Zaradcze (zabezpieczające) - ponieważ mają zapobiegać popełnieniu przestępstwa. Karne - bowiem sprawiają konkretną dolegliwość, jak: upokorzenie czy zawstydzenie za przekroczenie, które nie ma jeszcze znamion przestępstwa, ale dla przestępcy jest już okazją do popełnienia go lub też budzi podejrzenie, że przestępstwo zostało popełnione. Środki zaradcze mają incydentalnie na celu również ukaranie przestępcy, w tym znaczeniu, że zastępują właściwą karę lub ją obostrzają ${ }^{55}$.

W sytuacji, gdy środki te pełnią jedynie funkcję prewencji specjalnej, nie posiadają charakteru odwetu i stąd zbliżają się do środków zabezpieczających, przewidywanych przez państwowe kodeksy karne. Jeśli natomiast zastępują karę lub ją zwiększają, wtedy utożsamiają się z kara, na skutek występowania w nich treści odwetu. Prawodawca kościelny wprowadza do Kodeksu charakterystyczną dwutorowość; w postaci kary i środków zaradczych. Nadto, tę dwutorowość rozwija i poszerza dodatkowo przewidując pokuty, które nakłada ordynariusz w tym celu, aby przestępca uniknął kary lub uzyskał jej darowanie (kan. $2312 \S 1)^{56}$. Mimo

habetur loco poenae vel fit ad augendam poenam, praecipue si agatur de recidivo. $\S 5$. De monitione et correptione, etsi secreto factae fuerint, constare debet ex aliquo documento in secreto archivo Curiae asservando. $\S 6$. Tam correptio quam monitio fieri potest semel vel pluries, pro Superioris arbitrio et prudentia. Can. 2310. Monitionibus et correptionibus incassum factis, vel si ex eisdem effectum sperare non liceat, datur praeceptum, quo quid agere quidve evitare praeventus debeat, accurate indicetur, cum poenae comminatione in casu transgressionis. Can. 2311. $\S 1$. Si casus gravitas ferat et praecipue si agatur de eo qui in periculo versetur relabendi in idem crimen, eum Ordinarius submittat vigilantiae. $\S 2$. Vigilantia praecipi quoque potest ad augendam poenam, praecipue in recidivos. Can. 2312. § 1. Poenitentiae in foro externo imponuntur ut delinquens vel poenam effugiat, vel poenae contractae absolutionem aut dispensationem recipiat. $\S 2$. Ob delictum aut transgressionem occultam nunquam poenitentia publica imponatur. $\S 3$. Poenitentiae non tam secundum quantitatem delicti, quam secundum poenitentis contritionem moderandae sunt, pensatis qualitatibus personarum et delictorum adiunctis. Can. 2313. §1. Praecipuae poenitentiae sunt praecepta: $1^{\circ}$ Recitandi determinatas preces; $2^{\circ}$ Peragendi piam aliquam peregrinationem vel alia pietatis opera; $3^{\circ}$ Servandi peculiare ieiunium; $4^{\circ}$ Erogandi eleemosynas in pios usus; $5^{\circ}$ Peragendi exercitia spiritualia in pia aut religiosa domo per aliquot dies. $\S 2$. Poenitentias Ordinarius pro sua prudentia addere potest poenali remedio monitionis et correptionis".

55 Por. F. Bączkowicz, Prawo kanoniczne..., t. 2, s. 598.

${ }_{56}$ „Przez pokutę rozumiemy pewne pobożne uczynki nałożone przez ordynariusza w zakresie zewnętrznym w tym celu, by przestępca uniknął kary lub uzyskał odpuszczenie kary już nałożonej (kan. $2312 \S 1$ ). Pokutę tę nazywają autorzy kanoniczną w odróż- 
wszystko jednak w pokutach nałożonych przez władzę kościelną występuje element odwetu, jednakże w bardziej umiarkowanej formie niż w karach. W następstwie pojawiającego się pierwiastka odwetu raczej powinno się je zaliczyć do środków karnych niż do zabezpieczających ${ }^{57}$.

Dla porównania polski Kodeks karny z 1932 roku znał trzy rodzaje przepisów karnych: dla dorosłych, co do których stosowana była zasada odpłaty, z możliwością odstąpienia od niej warunkowo; kolejno dla nieletnich, gdzie w zasadzie wykluczano odpłatę, a karę zastąpiono środkami wychowawczymi (art. $69 \S 2)^{58}$, utrzymując możliwość stosowania jej w wyjątkowych wypadkach; oraz dla osób niebezpiecznych społecznie były to środki zabezpieczające, w których czynnik odwetowy był zupełnie wykluczony (art. 79-85) ${ }^{59}$. Z tego powodu, w Kodeksie tym wytwarzała się

nieniu od sakramentalnej, zadawanej przez spowiednika penitentowi w celu zadośćuczynienia Panu Bogu za odpuszczony grzech". F. Bączkowicz, Prawo kanoniczne..., t. 2, s. 600.

57 J. Makarewicz, Prawo..., s. 23, M. Myrcha, Prawo karne..., s. 30.

58 „Rozdział XI. Postępowanie z nieletnimi. Art. 69 § 2. Do tych nieletnich sąd stosuje tylko środki wychowawcze, a mianowicie: upomnienie, oddanie pod dozór odpowiedzialny rodzicom, dotychczasowym opiekunom lub specjalnemu kuratorowi, albo umieszczenie w zakładzie wychowawczym".

59 „Rozdział XII. Środki zabezpieczające. Art. 79. Jeżeli sprawcę czynu zabronionego pod groźbą kary uznano za nieodpowiedzialnego, a jego pozostawanie na wolności grozi niebezpieczeństwem porządkowi prawnemu, sąd zarządza jego umieszczenie w zamkniętym zakładzie dla psychicznie chorych albo w innym zakładzie leczniczym. Art. 80. § 1. Jeżeli przestępcę uznano za mającego zmniejszoną zdolność rozpoznawania lub kierowania postępowaniem (art. $18 \S 1$ ), a jego pozostawanie na wolności grozi niebezpieczeństwem porządkowi prawnemu, sąd może zarządzić jego umieszczenie w zamkniętym zakładzie dla psychicznie chorych albo w innym zakładzie leczniczym. § 2. Jeżeli takiego przestępcę sąd skazał na karę pozbawienia wolności, to o tem, czy orzeczoną karę wykonać, sąd rozstrzyga po zwolnieniu przestępcy z zakładu leczniczego. Art. 81. Czasu pobytu w zakładach, wymienionych w art. 79 i 80, nie oznacza się z góry. Sąd nie może zarządzić zwolnienia z zakładu wcześniej, niż po upływie jednego roku. Art. 82. §1. Jeżeli czyn pozostaje w związku z nadużywaniem napojów wyskokowych lub innych środków odurzających, sąd może zarządzić, by sprawcę, po ewentualnem odbyciu wymierzonej kary, umieszczono w odpowiednim zakładzie leczniczym na przeciąg 2 lat. § 2 . O wcześniejszem zwolnieniu z zakładu rozstrzyga sąd. Art. 83. § 1. Jeżeli czyn pozostaje w związku ze wstrętem do pracy, sąd może zarządzić, by po odbyciu kary umieszczono przestępcę w domu pracy przymusowej na przeciąg lat 5 . § 2 . Po upływie jednego roku sąd może zarządzić zwolnienie. Art. 84. § 1. Sąd zarządza umieszczenie w zakładzie dla niepoprawnych, po odbyciu kary, przestępcy, u którego stwierdzono trzykrotny powrót do przestępstwa (art. $60 \S 1$ ), tudzież przestępcy zawodowego lub z nawyknienia, jeżeli pozostawanie ich na wolności grozi niebezpieczeństwem porządkowi prawnemu. § 2. Zamknięcie w zakładzie trwa w miarę potrzeby, w każdym razie najmniej 5 lat; po upływie każdego pięcioletniego okresu sąd rozstrzyga, czy pozostawienie przestępcy w zakładzie na dalszy okres pięcioletni jest konieczne. Art. 85. Jeżeli sprawcę czynu zabronionego pod groźbą kary uznano za 
dwutorowość, w postaci kary i środków zabezpieczających, podobnie jak to miało miejsce i w Kodeksie Pio-Benedyktyńskim z 1917 roku.

S. Śliwiński utrzymuje, że „,́́rodek zabezpieczający wykazuje niewątpliwie pewne pokrewieństwa z myślą prewencji szczególnej. Ustawa wychodzi z założenia, że kara o najdalej posuniętym pierwiastku prewencji szczególnej nie zawsze może być wystarczająca. Kara, jako odwet, musi pozostawać w pewnej proporcji do czynu, dolegliwość celowa, tkwiąca w istocie kary, nawiązuje do samego czynu przestępczego, jego wagi, jak również do osoby sprawcy, jego winy i podmiotowych właściwości. Kara, która by nie stała w pewnym stosunku do czynu i winy, byłaby karą niesprawiedliwą. Jednakże konieczność zabezpieczenia społecznego przed niebezpiecznym osobnikiem narzuca się z taką siła, że nie można o niej zapomnieć, gdy czyn przestępczy lub czyn zabroniony pod groźbą kary sygnalizuje dalsze istnienie niebezpieczeństwa społecznego, nawet po wykonaniu kary. W takich przypadkach ustawa sięga do środka zabezpieczającego. Gdy sprawca czynu przestępczego jest odpowiedzialny i rachunek jego ze społeczeństwem z tytułu odwetu (kary), chociażby nie pozbawionej wybitnych pierwiastków prewencji szczególnej, jest wyrównany, trzeba czasem sięgnąć do środka ochrony społecznej, mianowicie do środka zabezpieczającego, gdy jest widoczne, że mimo wykonania kary niebezpieczeństwo nadal niewątpliwie istnieje. Teraz rozpoczyna się przejaw działalności państwowej, który nie ma nic wspólnego z karą. Tak obłąkany, który popełnił czyn zabroniony pod groźbą kary dostania się do zamkniętego zakładu psychiatrycznego, może na całe życie (art. 79, 81), jak i niepoprawny przestępca, który umieszczony zostanie po odbyciu kary w zakładzie dla niepoprawnych, może także na całe życie (art. 84), wreszcie, tak samo chory psychicznie, który nie popełnił żadnego czynu zabronionego pod groźbą kary, a w zakładzie dla obłąkanych także żywota dokonać musi, znajdują się na jednej płaszczyźnie, ale nie pod względem ich traktowania, pozbawionego wszelkich pierwiastków kary, w szczególności odpłaty, lecz jedynie zapobieżenia. Uzasadnienie i cel środków zabezpieczających, to tylko ochrona społeczeństwa przed niebezpiecznym osobnikiem, który naruszył porządek prawny, czasem w sposób zawiniony, czasem nawet niezawiniony (osobnik nieodpowiedzialny). Stosowanie środków zabezpieczających to właściwie posunięcie 
natury administracyjnej, przekazane sądowi dlatego, że okazję do stosowania tych środków daje przestępstwo albo przynajmniej czyn zabroniony pod groźbą kary" ${ }^{\prime 60}$.

Konkludując, należy stwierdzić, że szkoła klasyczna przyjmuje wszystkie wskazane cele, upatrując w odwecie cel najistotniejszy. Szkoła pozytywna natomiast odrzuca idee odwetu (odpłaty), a w miejsce jej wprowadza środki ochrony społecznej. Poprawę - jako cel - przyjmuje, ale zmienia zasadnicze znaczenie poprawy. Zatem przez poprawę należy rozumieć nie zaniechanie czynienia zła, odstąpienie od czynu nieprawego, lecz wyleczenie sprawcy $\mathrm{z}$ ",choroby" i uwolnienie go od złego upodobania. Powyższa szkoła wyklucza odstraszenie jako cel kary, twierdząc, że rygorami karnymi nie zapobiegnie się przestępstwom ${ }^{61}$.

\section{Zakończenie}

Kościół swej władzy karania nie uważa za pierwszorzędny sposób prowadzenia wiernych do uświęcenia i zbawienia. Karanie jest niewątpliwie środkiem dalszym ad animarum salutem procurandam. Kościół kieruje wiernych do właściwego im celu przede wszystkim poprzez nauczanie Słowa Bożego, udzielanie sakramentów, zachęty, perswazje, upomnienia ojcowskie, ustawy dyscyplinarne. Niekiedy jednak, ze względu na dobro duchowe wiernego, który dopuścił się czynu zakazanego oraz dobro wspólnoty, sprawiedliwe ukaranie przestępcy jest konieczne. Z karaniem przestępców spotykamy się w Kościele od początku jego istnienia. Już św. Paweł zmuszony był korzystać z prawa do karania. Początkowo wymierzano karę ekskomuniki, czyli wykluczenia ze społeczności wiernych. Kolejno karano za przestępstwa wielkie i jawne, zwłaszcza za tak zwane crimina capitalia, do których zaliczano przede wszystkim odstępstwo od wiary i bałwochwalstwo, zabójstwo, rozpustę. Pojednanie ukaranych z Kościołem mogło nastąpić po wypełnieniu surowych warunków, między innymi po odbyciu pokuty publicznej. Pokuta ta miała charakter re-

${ }^{60}$ S. Śliwiński, Prawo..., s. 439-440, M. Myrcha, Prawo karne..., s. 31-32.

${ }^{61}$ Por. S. Śliwiński, Prawo..., s. 430, M. Myrcha, Prawo karne..., s. 32. 
alnej kary, gdyż zmierzała nie tylko do zadośćuczynienia Bogu za winy, lecz także do naprawienia kościelnego porządku społecznego ${ }^{62}$.

Kara jest dolegliwościa, cierpieniem, złem, jakkolwiek może i powinna być lekarstwem i dobrodziejstwem dla duszy i ciała. Polega ona na pozbawieniu przestępcy jakiegoś dobra prawnego lub duchowego (urzędu, prawa przyjmowania sakramentów) bądź też doczesnego (wolności, czci, majątku). Ustanawianie kary ma zawsze na uwadze jakiś określony cel. Prawodawca wylicza dwa podstawowe cele, które się wzajemnie przenikają: poprawa przestępcy i potępienie samego przestępstwa. Ogólnym, podstawowym celem kary kościelnej jest punitio delicti, odpłata (odwet) za wyrządzoną szkodę publiczna, przywrócenie naruszonego przestępstwem porządku społecznego, usunięcie zgorszenia, odstraszenie od przestępstwa innych, zadośćuczynienie poczuciu sprawiedliwości i prawa. Celem szczególnym jest correctio delinquentis, poprawa przestępcy, który pod wpływem doznanej dolegliwości, którą wywołała kara, łatwiej zmieni swą złą wolę.

Niniejszy historyczno-prawny artykuł nie przyczyni się z pewnością do zmiany obowiązującego w Kościele, czy też w Polsce, prawa karnego nie taki też był jego cel. Mam jednak nadzieję, że stanie się przyczynkiem do dalszych podobnych rozważań w zbliżającą się setną rocznicę promulgacji Kodeksu Prawa Kanonicznego z 1917 roku.

Słowa kluczowe: karanie w Kościele, pojęcie i cel kary w Kościele, kościelne prawo karne

\section{Bibliografia:}

Ambroziak W., Od kaźni i tortur do uwięzionej socjalizacji. O genezie i rozwoju systemu profilaktyki i resocjalizacji, „Studia Edukacyjne” 24 (2013), s. 27-36.

Bączkowicz F., Prawo kanoniczne. Podręcznik dla duchowieństwa, t. 2, Kraków 1933.

Bączkowicz F., Prawo kanoniczne. Podręcznik dla duchowieństwa, t. 3, Opole 1958. Belina-Prażmowska P., Dlaczego czynimy zło? Trójpodziat przyczyn zła moralnego według św. Tomasza z Akwinu, „Rocznik Tomistyczny” 2014, z. 3, s. 113-127.

${ }^{62}$ Por. T. Pawluk, Prawo kanoniczne według Kodeksu Jana Pawła II. Doczesne dobra Kościoła. Sankcje w Kościele. Procesy, Olsztyn 1990, s. 65-66. 
Chauvin T., Stawecki T., Winczorek P., Wstęp do prawoznawstwa, Warszawa 2014.

Ciepły F., Środki zabezpieczające według koncepcji J. Makarewicza, [w:] A. Grześkowiak (red.), Prawo karne w pogladach Profesora Juliusza Makarewicza, Lublin 2005.

Grześkowiak A., Wiak K., Gałązka M., Hałas R., Hypś S., Szeleszczuk D. (red.), Kodeks karny z 1932 roku, Lublin 2015.

Lyons L., Historia kar cielesnych, Warszawa 2010.

Makarewicz J., Prawo karne. Wykład porównawczy z uwzględnieniem prawa obowiąującego w RP, Lwów-Warszawa 1924.

Myrcha M., Prawo karne. Komentarz do Piątej Księgi Kodeksu Prawa Kanonicznego. Kara - część I - przepisy ogólne, Warszawa 1960.

Ostaszewski K., Makarewicz Juliusz, [w:] Encyklopedia Katolicka, t. 11, Lublin 2006.

Paczos K., Niewiele mniejszy od aniołów. Zagadnienia podstawowe z filozofii wyższej warstwy duszy ludzkiej. Perspektywa Arystotelesa i św. Tomasza z Akwinu, Gdańsk 2005.

Papierkowski Z., Socjologiczne i filozoficzne oblicze kary, Lublin 1947.

Paprzycki L.K., System środków zabezpieczających w ujęciu Kodeksu karnego z 1932 r. - koncepcja i rzeczywistość, [w:] A. Grześkowiak, K. Wiak, M. Gałązka, R. Hałas, S. Hypś, D. Szeleszczuk (red.), Kodeks karny z 1932 roku, Lublin 2015.

Pawluk T., Prawo kanoniczne według Kodeksu Jana Pawła II. Doczesne dobra Kościoła. Sankcje w Kościele. Procesy, Olsztyn 1990.

Renken J.A., The Penal Law of the Roman Catholic Church. Commentary on Canons 1311-1399 and 1717-1731 and Other Sources of Penal Law, Ottawa 2015.

Sztafrowski E., Prawo kanoniczne w okresie odnowy soborowej. Podręcznik dla duchowieństwa, t. 2, Warszawa 1979.

Śliwiński S., Prawo karne, Warszawa 1946.

Wilemska E., Kary kościelne, [w:] Encyklopedia Katolicka, t. 8, Lublin 2000.

Wójcik W., Krukowski J., Lempa F. (red.), Komentarz do Kodeksu Prawa Kanonicznego z 1983 r. Księga V - Dobra doczesne Kościoła, Księga VI - Sankcje w Kościele, t. 4, Lublin 1987.

\section{THE CONCEPT AND PURPOSE OF A PENALTY IN THE CHURCH AN OUTLINE OF LEGAL HISTORY}

\section{$\mathrm{S} \mathbf{u} \mathbf{m} \mathbf{m}$ a $\mathbf{r} \mathbf{y}$}

The Church has its own inherent right to punish its faithful, a right which is independent of any human authority. However, those who hold this right must remember that first and foremost, they are shepherds of their flock, and not the judges inflicting penalties. Hence, penal sanctions should be a last re- 
sort to be used only when other measures are not effective, as the Code of 1917 points out. A penalty can be defined as a response to some behavior that violates the rules or prohibitions in force. By its nature, it should involve material or spiritual hardship. It should inflict suffering on the offender or deprive the offender of some good, such as life, freedom, property, certain spiritual benefits, or privileges enjoyed in a social group. Moreover, a penalty should be imposed only by the appropriate legitimate authority (e.g. church authorities). A penalty can only be inflicted for a committed offence, because in its nature it is a retaliation carried out by society against the offender for violating the legal order. If there has been no offence, there is no legal right to inflict a penalty. However, apart from determining what a penalty is, it is also necessary to examine its purpose. This part of the philosophy of punishment can provide an answer to the question why there are penal sanctions and how they are justified. It should be emphasized that the purpose of a penalty justifies its use and undoubtedly, entitles the Church or the state to impose it. As the history of canon law shows, penalties applied by the Church have served different purposes. Referring to St. Augustine's teaching, the Decretum Gratiani emphasised that penalties were justified only in so far as they contributed to the betterment of the offender and other people. Therefore, it seems useful to examine historical and legal issues connected with the subject of this article.

Key words: penalties in the Church, concept and purpose of a penalty in the Church, ecclesiastical penal law

\section{ПОНЯТИЕ И ЦЕЯИ НАКАЗАНИЯ В ЦЕРКВИ. ИСТОРИКО-ПРАВОВОЙ РИС}

\section{P e 3 го м}

Церковь имеет свое собственное, присущие и независимое от любого человеческого закона право наказывать подчиненных верующих. Те, кто имеют на это право, должны помнить, что прежде всего они явдяются пастырями своей паствы, а не темы кто применяет наказание. Следовательно, применение уголовных санкций является последним средством, когда другие меры не дают результатов. Наказанием является реакция на поведение человека, который идет против нынешних запретов. По своей природе наказание должно быть материальным или духовным недугом. Должно быть в значительной мере страданием или лишить преступника его некоторых ценностей, таких как жизнь, свобода, собственность определенных привилеев душевных или привилегий в социальной группе. Последовательно наказание должно быть наложено на правонарушителя только законной властью. Наказание применяется только за совершенное преступление, потому что наказание по своей сути применяется в качестве возмездия на правонарушителя. Если преступление не существовало, не существовало также законное право на применение 
наказания. Понятие приговора было бы неполным, если бы остановиться на вопросе чем оно является а не его цели. Возможно, это относится к философии наказания и дает нам ответ на вопрос, что такое наказание и что является его обоснованием. Следует подчеркнуть, что цель наказания оправдывает его использование, и несомненно, дает Церкви или государству право на его применение. В истории канонического права находятся различные цели наказания в Церкви. Постановление Грациана, опираясь на науке Святого Августина утверждал, что наказание оправдано постольку, поскольку она способствует улучшению преступников и других людей. Таким образом, представляется целесообразным приближение исторических и правовых вопросов, определенных в теме этой статьи.

Ключевые слова: наказание в Церкви, понятие и цель наказания в Церкви, церковное уголовное право 